\title{
Typification and application of the name Arctotis grandiflora Aiton (Asteraceae: Arctotideae)
}

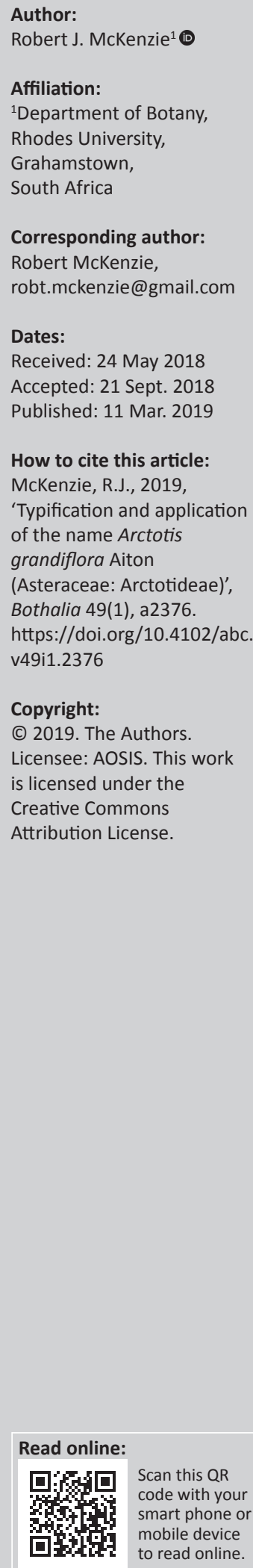

Background: Ongoing taxonomic studies in the African genus Arctotis (Asteraceae) necessitate periodic nomenclatural adjustments and corrections.

Objectives: To evaluate the taxonomic status and application of the name Arctotis grandiflora Aiton.

Methods: Type material and herbarium specimens were located and examined, relevant literature was consulted and wild populations were observed.

Results: The type material of A. grandiflora Aiton comprises specimens of two taxa from independent gatherings. A lectotype is designated for A. grandiflora.

Conclusion: The name A. grandiflora Aiton is a heterotypic synonym of Arctotis stoechadifolia P.J.Bergius. A revised synonymy for $A$. stoechadifolia is presented.

\section{Introduction}

Arctotis L. is a genus of approximately 70 species distributed in southern Africa as far north as southern Angola and southern Zimbabwe. The centre of diversity of the genus is in the winter rainfall region of South Africa, where it is a conspicuous element of the Fynbos and Succulent Karoo biomes. Arctotis has a long history of taxonomic and nomenclatural confusion. A thorough revision of the taxonomy and nomenclature of the genus is ongoing. A prerequisite for publication of a monograph of the genus, and for treatment of Arctotis in the e-Flora of South Africa (Le Roux et al. 2017), is the typification and correct application of all validly published names in the genus. While considerable progress has been made in this regard (e.g. McKenzie, Hjertson \& Barker 2008a, 2008b; McKenzie \& Barker 2010, 2013; McKenzie 2018), the status of numerous obscure names remains to be resolved. As a contribution to a revised taxonomy of Arctotis, the typification and application of the name Arctotis grandiflora Aiton was the focus of the present study.

Arctotis grandiflora Aiton was validly published by Aiton (1789) for a species cultivated in the Royal Botanic Garden at Kew. Aiton was the head gardener at the Kew gardens from 1759 to 1793 (Desmond 2007). Aiton (1789) provided the diagnosis 'A. flosculis radiantibus fertilibus, foliis pinnatifidis denticulatis arachnoideis trinerviis' and noted that the species was based on material collected from the Cape of Good Hope by Frances Masson. Masson was a gardener at Kew who collected in the Cape in 1772-1775 and 1786-1795 (Glen \& Germishuizen 2010). According to Aiton (1789), the species was introduced to the Royal Botanic Garden at Kew in 1774. No specimens or previous publications were cited in the protologue by Aiton. The original provenance of the species to which the name was applied was stated only to be the Cape of Good Hope (Aiton 1789); therefore, the natural distribution of the species is unknown.

Application of the name A. grandiflora Aiton has always been uncertain and has varied in treatments of Arctotis. Arctotis grandiflora is listed by Gmelin $(1792,1796)$ as an accepted species with the abbreviated diagnosis 'A. foliis pinnatifidis denticulatis arachnoideis trinerviis'. Arctotis grandiflora is not mentioned by Murray (1798). Willdenow (1803) treated A. grandiflora as a synonym of $A$. speciosa Jacq. Aiton (1813), however, resurrected A. grandiflora at the rank of species, repeating the diagnosis ' $A$. foliis pinnatifidis denticulatis arachnoideis trinerviis' used by Gmelin, supplemented with observations of the ray and disc floret colourations, and that the plant was caulescent and the rays were large. Sprengel (1827) noted that A. grandiflora Aiton differs from A. grandiflora Jacq., which was based on a form of A. revoluta Jacq. (McKenzie 2018). The name A. grandiflora Jacq. is a heterotypic homonym (Turland et al. 2018, Art. 53.1) of A. grandiflora Aiton; therefore, Sprengel (1827) published the replacement name A. massoniana Spreng. In their 
treatments of Arctotis, neither Lessing (1832) nor Harvey (1865) mentioned the name A. grandiflora Aiton, although the newly published names of Aiton (1789) from other genera separate to Arctotis were mentioned. Candolle (1838) recognised the name $A$. grandiflora Aiton as a synonym of A. elongata Thunb., unfortunately citing no reason for the decision. The name was not cited in the most recent monographs of Arctotis (Beauverd 1915; Lewin 1922). McKenzie (2012) listed A. grandiflora Aiton under 'Excluded species' and noted that it was described from cultivated material and was known only from the type.

\section{Materials and methods}

I examined the types as well as all relevant material lodged in BOL, G, G-DC, G-PREL, GRA, NBG, PRE, S, SAM, SBT and UPS-THUNB. In addition, a high-resolution digital image of material lodged in BM was examined (acronyms follow Thiers 2018). Wild populations were studied in the field in the Western Cape province of South Africa.

\section{Results and discussion}

The only known extant herbarium material annotated with the name $A$. grandiflora and unequivocally prepared from material cultivated in the Royal Botanic Gardens, Kew, is a single sheet lodged in the Herbarium of the Natural History Museum, London (BM). Almost all types for new taxa described by Aiton (1789) are lodged in BM (Stafleu \& Cowan 1976). The sheet is annotated at the base with 'Arctotis grandiflora MS -Sol. in Hort. Kew. iii. 272!' and 'Arctotis elongata, Thb'. (Figure 1). The sheet also bears a handwritten label inscribed with '1 Hort Kew 1777 Sem. e cap. bon. spei' and ' $2-1779$ '. The material mounted on the sheet consists of two leafy fertile shoots, one with a single, terminal, severely insect-damaged capitulum, pressed in face view, that was probably at anthesis, and the other shoot with a single immature capitulum in very early development. In addition, two detached leaves and a detached pedunculate capitulum, also insect damaged, are mounted on the sheet. The shoot bearing the badly insect-damaged capitulum is annotated with ' 1 ' on the mounting tape at the base of the shoot, whereas the other specimens are not annotated with a number. It is interpreted that the specimens were prepared in 1777 and 1779 from plants grown at Kew from seeds collected from 'Caput bonae spei'. For typification purposes, the specimens are treated as two gatherings: one gathering comprising a single shoot prepared in 1777 (BM000895056; hereafter termed 'gathering 1'); the remaining material is presumed to have been prepared in 1779 (BM000895058; hereafter collectively termed 'gathering 2'). Preparation of both gatherings preceded publication of the name A. grandiflora in 1789 and thus both can be considered for selection as lectotype.

The 'gathering 1' shoot bears nine leaves on the lower half of the stem, with a short axillary shoot near the stem base. The basalmost leaves are variably lobed to pinnatifid or pinnatisect, and oblanceolate to lanceolate-elliptic in shape.

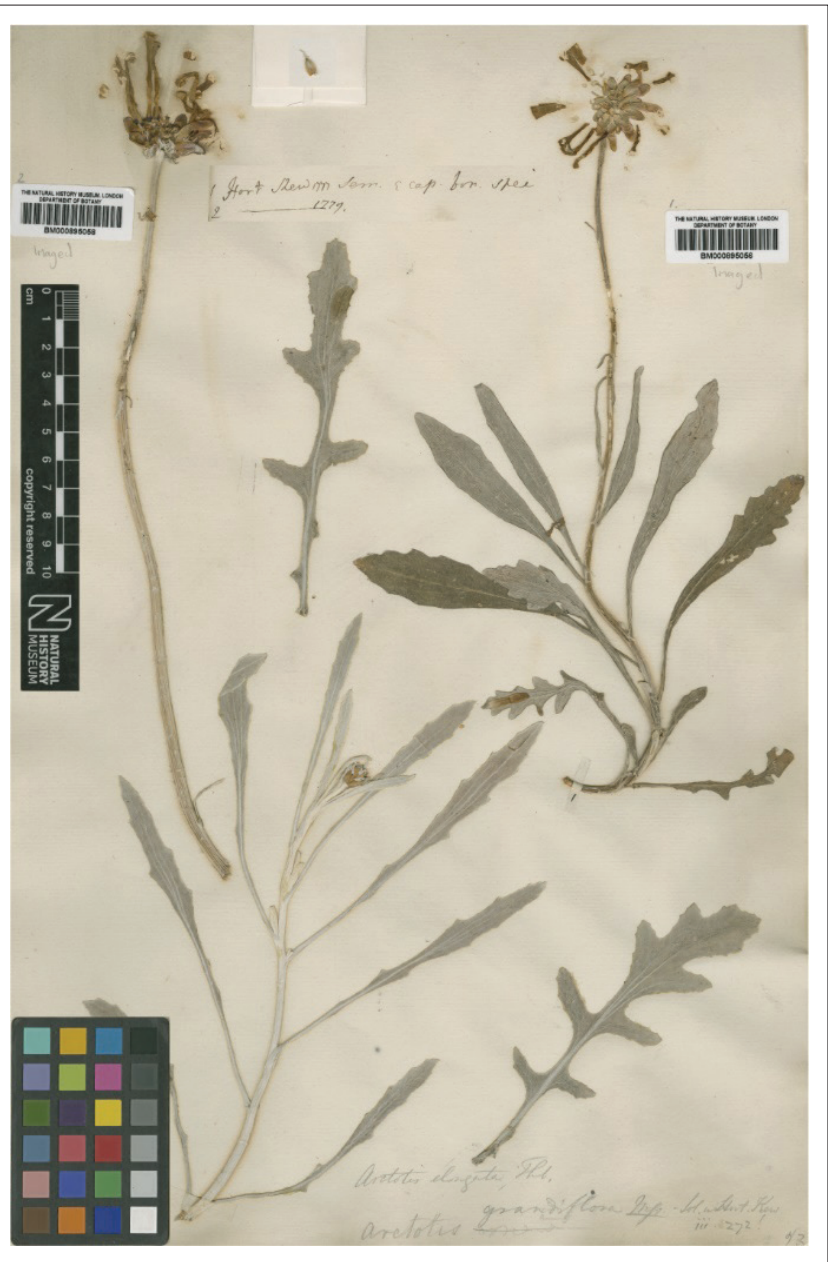

Source: Reproduced under the terms of the Creative Commons Attribution License [CC BY 4.0] (http://creativecommons.org/licenses/by/4.0), (c) The Trustees of the Natural History Museum, London

FIGURE 1: Type material for Arctotis grandiflora Aiton (BM000895056 and BM000895058).

The middle and upper leaves are simple, oblanceolate to oblanceolate-linear with the margin weakly sinuate to entire and not strongly revolute. Collectively, the leaves are c. $6.5 \mathrm{~cm}-11.0 \mathrm{~cm}$ long $\times 0.5 \mathrm{~cm}-2.0 \mathrm{~cm}$ wide and acute or obtuse. A single terminal capitulum on a peduncle about $10 \mathrm{~cm}$ long is borne above the uppermost true leaf. Unfortunately, the capitulum is severely insect-damaged and is of little value for identification, but the involucre is consistent with that of an Arctotis species: oblong-obovate inner involucral bracts with a slightly translucent distal portion and obtuse apex, ovate-oblong middle bracts with a thin darker margin and ovate-triangular outer bracts with a short, linear apical appendage. The peduncle is densely tomentose and lacks multiseptate trichomes. The lamina surface is discolourous with a sparsely tomentose adaxial surface and with a densely tomentose abaxial surface that is not obviously scabrid or glandular. The apex is acute and not distinctly mucronate. The lamina base is tapering, simple, narrow and not auriculate.

The combination of characters described above is not readily applicable to any currently recognised species. More than 20 Arctotis species are caulescent with discolourous leaves. 
An important consideration is that the 'gathering 1' specimen was prepared from a cultivated plant. Some Arctotis species show considerable phenotypic plasticity and certain species, such as A. bellidifolia P.J.Bergius, produce simple leaves in their natural habitats, while in cultivation they may produce lyrate-pinnatifid to lyrate-pinnatisect leaves when supplied with ample water and nutrients (personal observation). Thus, herbarium specimens prepared from wild and cultivated material of the same species may appear heterospecific.

The 'gathering 2' shoot has a terminal immature capitulum and about 10 leaves uniformly spaced along the stem. All of the leaves on the shoot are lanceolate, c. $4.0 \mathrm{~cm}-11.5 \mathrm{~cm}$ long $\times 0.50 \mathrm{~cm}-1.25 \mathrm{~cm}$ wide and acute. The lamina is densely tomentose on both surfaces, with the margin distantly dentate and not revolute. The leaf base is narrow, tapering, petiolate and non-auriculate. The stem is densely tomentose and lacks multiseptate trichomes. The absence of a distinct peduncle reflects the extremely early stage of capitulum development (in Arctotis, the peduncle elongates throughout capitulum development up until cypsela maturity). The two detached leaves differ in being pinnatisect, weakly lyrate, c. $13 \mathrm{~cm}$ long $\times 2 \mathrm{~cm}-4 \mathrm{~cm}$ wide, with three pairs of lateral lobes, obtuse, with a dentate-mucronate margin.

The detached capitulum is borne on a naked peduncle about $25 \mathrm{~cm}$ in length. The insect damage is less severe than on the 'gathering 1 ' shoot and the capitulum contains intact immature cypselae and florets. The outer involucral bracts have a tomentose, triangular-ovate base and a linear, tomentose non-membraneous apical appendage. The middle bracts are densely tomentose on the apical portion and the upper base, with dark pigmentation on the apical portion of the margin. The innermost bracts bear only a short narrow band of hairs along the centre; the margins and apical portion are glabrous. The disc florets have a funnelform corolla, with planate elaborations on the abaxial surface of the corolla lobes typical for Arctotis. The corolla lobes are blackish brown. The ray floret clearly has a broad dark band at the base of the limb on the adaxial surface. The cypsela is densely tomentose, with a whorl of basal twin hairs similar in length or longer than the cypsela. Obovate pappus scales longer than the cypsela are visible. Abaxial wings are not discernible on the cypsela because of the dense tomentum.

In all accessible characters described above, 'gathering 2' is consistent with all examined herbarium material of Arctotis stoechadifolia P.J.Bergius (see selected specimens examined). 'Gathering 2' fits the description of A. stoechadifolia by Bergius and also with the description and illustrations of that species presented by Norlindh (1964). The basal leaf shape of $A$. stoechadifolia is highly variable among examined herbarium specimens, ranging from lyrate-pinnatisect to elliptic-lanceolate. The two detached leaves of 'gathering 2' fall within the range of variation. In addition, Aiton's (1789:272) description of floret colouration in the protologue for A. grandiflora ('Petala straminea, subtus rubore tincta, supra prope basin lutescentia, ore nigropurpureo') is consistent with that of A. stoechadifolia (Figure 2). The ray floret limb of A. stoechadifolia is yellowish cream to cream in colour, which may be equated with Aiton's use of 'Petala straminea'. As noted by Norlindh (1964), herbarium specimens of A. stoechadifolia are often incomplete and may lack the basal portion of the stem bearing the basal leaves or mature cypselae.

It is concluded that 'gathering 2 ' is consistent with A. stoechadifolia. 'Gathering 1 ' is inferred to be a different species but the uncertain identification of the specimen discourages its designation as the lectotype. Therefore, the specimen BM000895058 is here designated the lectotype for A. grandiflora Aiton and the name is placed in the synonymy of $A$. stoechadifolia.

Candolle (1838) placed A. grandiflora Aiton as a synonym of $A$. elongata, a coastal species restricted in the Eastern Cape province (McKenzie 2018). While A. elongata also has lanceolate leaves densely tomentose on both surfaces, it is readily distinguishable from $A$. grandiflora by a usually conical involucre with appressed outer involucral bracts, and by having basal leaves that are not distinctly pinnatisect.

The lectotype of $A$. grandiflora possesses a suite of characters that collectively distinguish it from caulescent, densely tomentose Arctotis species other than A. stoechadifolia and A. elongata: narrow, strongly lanceolate upper leaves; the leaves lack mucronate teeth on the margin and auriculate base; outer involucral bracts with a glabrous base and a densely tomentose, linear, recurved apical appendage; and middle involucral bracts densely tomentose in the centre of the distal portion of the bract.

Norlindh (1964) resolved the correct application of the name A. stoechadifolia and included the names $A$. grandis Thunb. and the illegitimate name $A$. decumbens Thunb. (Turland et al. 2018, Art. 53.1) as heterotypic synonyms of A. stoechadifolia. The name Centaurea incana Burm.f. was based on material of A. stoechadifolia formerly in the Burman Herbarium (now in G-PREL; McKenzie 2018). The fertile shoot of BM000895058 is consistent in morphology with the lectotypes for A. stoechadifolia (SBT10247; Figure 3) and C. incana (G-PREL G00803829; for image, see McKenzie 2018). Both of these specimens, as also the lectotype of $A$. grandis (UPS-THUNB 20773), lack the decumbent, adventitiously rooting, densely leafy basal portion of the stem bearing the typically pinnatisect basal leaves; these features are well illustrated in the lectotype for A. decumbens Thunb. (UPS-THUNB 20763; Figure 4).

Stafleu and Cowan (1976) stated that the botanical descriptions in volume 3 of Hortus kewensis (Aiton 1789) were mainly prepared by Jonas Dryander, who was employed in the Banksian Herbarium. The pencilled annotation at the base of the type sheet includes 'A. grandiflora MS -Sol.', which suggests that at least the 

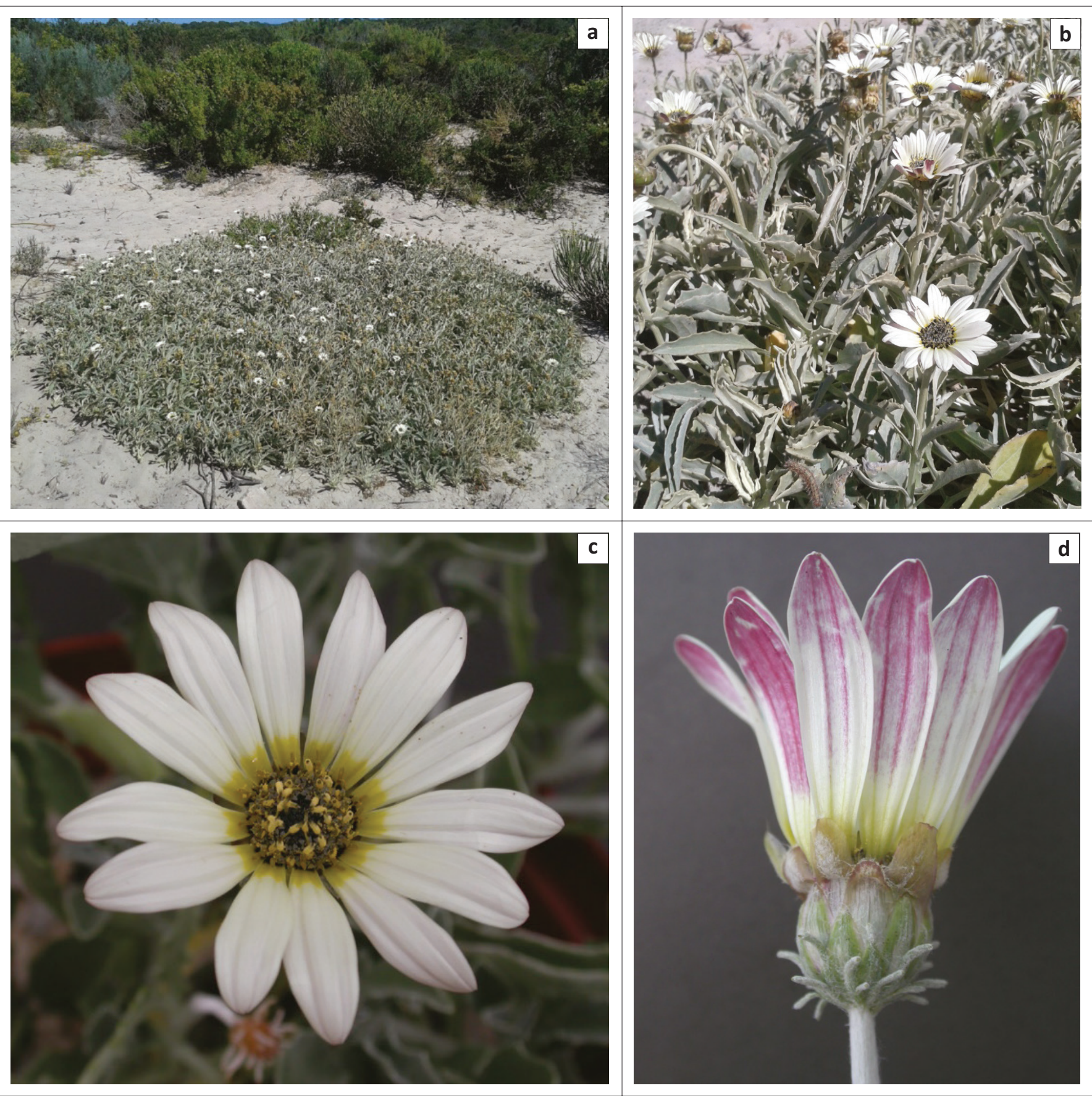

Source: Photos courtesy of D.G. Gwynne-Evans (a) and (b) and R.J. McKenzie (c) and (d)

FIGURE 2: Morphology of Arctotis stoechadifolia: (a) and (b) plants at Western Cape, Elandsbaai and (c) and (d) capitula of plants at Western Cape, Melkbosstrand.

name was attributable to Daniel Solander, who curated the Banksian Herbarium until his death in 1782 and compiled many species descriptions in unpublished manuscripts (Diment \& Wheeler 1984; Rose 2018). The handwriting on the attached label and of the pencilled annotations on the type sheet is inconsistent with that of Solander and Dryander, and seems likely to have been written by different amanuenses employed as assistants and writers in the herbarium (cf. Marshall 1978). Under ICN Art. 46.5 (Turland et al. 2018), the authority for the name A. grandiflora is attributed to Aiton because there is no indication in the published work that either Solander or Dryander provided the validating description for
A. grandiflora. On the basis of the annotation on the type sheet, the author citation 'A. grandiflora Sol. ex Aiton' might be justified, but examination of unpublished manuscripts in BM for a description of A. grandiflora in Solander's handwriting would be required.

\section{Taxonomic treatment}

Arctotis stoechadifolia P.J.Bergius, Descr. Pl. Cap.: 324 (1767). 'Arctotis stoechadifolia var. bergii' DC., Prodr. 6: 488 (1838), nom. inval. (Art. 26.2). Type (designated by Norlindh 1964:201): South Africa, Cap. b. sp. [Caput bonae spei], s.d., M. Grubb s.n. (SBT10247!, lecto.). 


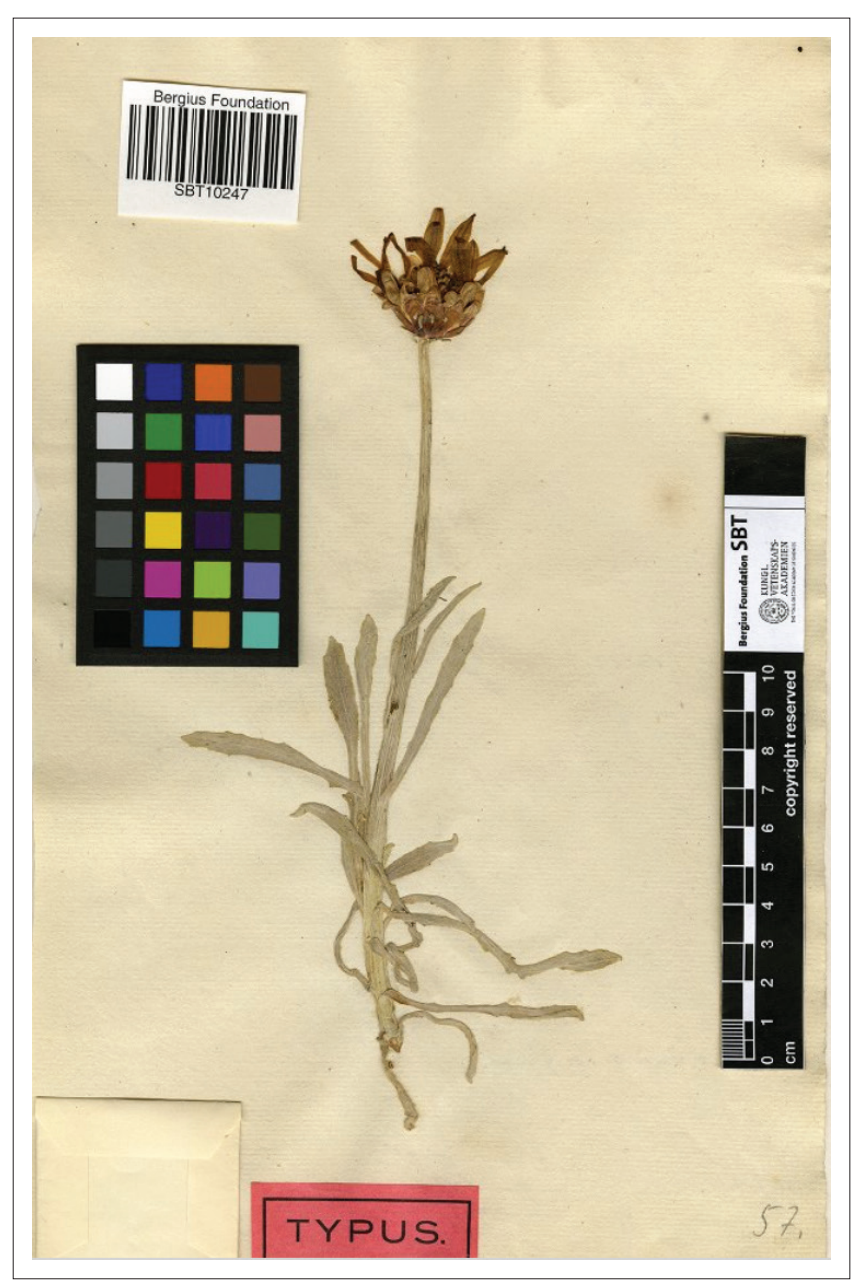

Source: Reproduced by kind permission, (c) The Bergius Foundation at the Royal Swedish Academy of Sciences

FIGURE 3: Lectotype of Arctotis stoechadifolia P.J.Bergius (SBT10247).

Centaurea incana Burm.f., Fl. Indica, Fl. Cap. Prodr.: 28 (1768). Type (designated by McKenzie 2018:46): Cap. bonae spei [Caput bonae spei], s.d., s.coll., ex Herb. Delessert (G-PREL G00803829!, lecto.).

Arctotis grandiflora Aiton, Hort. Kew. 3: 272 (1789), syn. nov. Type (designated here): Hort. Kew. Sem. e cap. bon. spei [Hortus Kewensis semen e Caput bonae spei], 1779, s.coll. (BM000895058 - image!, lecto.).

Arctotis grandis Thunb., Arctotis: 5 (1799). Arctotis stoechadifolia var. grandis (Thunb.) Less., Syn. Gen. Compos.: 26 (1832). Type (designated by Norlindh 1964:201): South Africa, Cap. b. spei [Caput bonae spei], s.d., C.P. Thunberg s.n. (UPSTHUNB 20773!, lecto.).

Arctotis decumbens Thunb., Arctotis: 5 (1799), nom. illeg. (Art. 53.1), non Arctotis decumbens Jacq., P1. Hort. Schoenbr. 3: 68 (1798). Arctotis stoechadifolia var. decumbens Less., Syn. Gen. Compos.: 26 (1832). Type (designated by Norlindh 1964:201): South Africa, Cap. b. spei [Caput bonae spei], s.d., C.P. Thunberg s.n. (UPS-THUNB 20763!, lecto.).

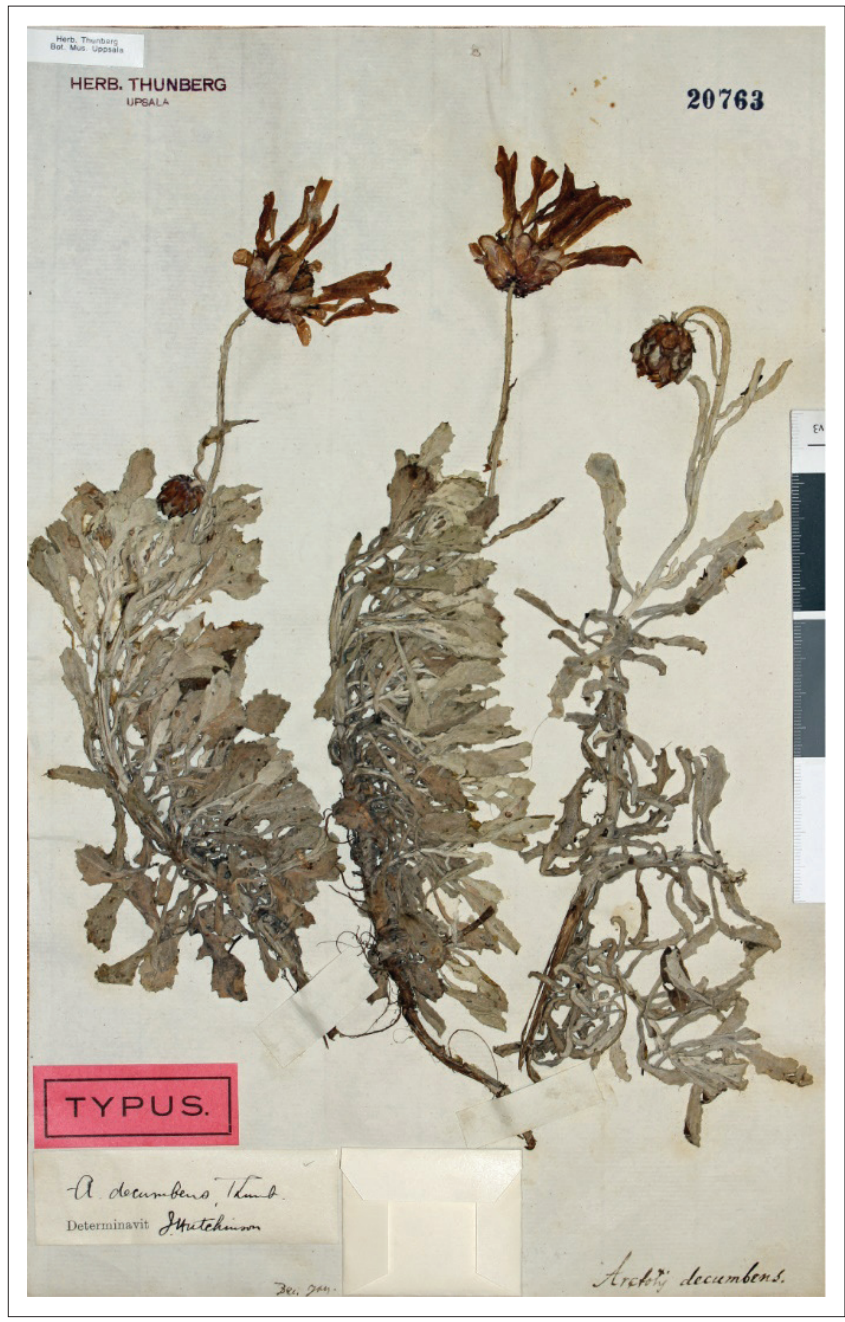

Source: Reproduced under the terms of the Creative Commons Attribution License [CC BY 4.0] (http://creativecommons.org/licenses/by/4.0), (c) Museum of Evolution, University of Uppsala

FIGURE 4: Lectotype of Arctotis decumbens Thunb. (UPS-THUNB 20763).

\section{Selected specimens of A. stoechadifolia examined}

SOUTH AFRICA: Western Cape.-3318 (Cape Town): stony sandstone slopes of Rondeberg along R27 (-AD), 14 Oct. 1995, P. Goldblatt \& J.C. Manning 10356 (NBG757267; PRE839293); Zwartland, Riebeekkasteel and Paardeberg (-BD/DB), 1835, C.F. Ecklon 447 (G-DC); Melkbosch, littoral dunes (-CB), 5 Jan. 1977, C. Boucher 3345 (NBG); south of Strand railway, Stikland (-CD), Sep. 1932, J.P.H. Acocks 1012 (S08-11651); sandy dunes along R27 between Melkbos and Blouberg (-CD), 7 Oct. 1995, P. Goldblatt \& J.C. Manning 10336 (NBG757257); in arina mobilis ad Kuylsrivier (-CD), Nov., C.W.L. Pappe s.n. (S08-11655); Cape Flats (-CD/DC), Nov., C.L.P. Zeyher 967 (BOL111727; G; SAM39948). 3418 (Simon's Town): near Upper North Battery, Simons Town (-AB), Sep. 1896, A.H. Wolley Dod 1695 (BOL111726); sandy hills NW of Simons Town (-AB), 8 Sep. 1918, N.S. Pillans 3219 (BOL111725); Cape Peninsula, sandy flats south of Retreat Vlei (-AB), 19 Nov. 1933, T.M. Salter 4008 (BOL111728); Springholsgat just south of Olifantsbos, CGHNR [Cape of Good Hope Nature Reserve] (-AB), 6 Oct. 1967, H.C. Taylor 7160 (NBG); Cape Point, Buffels Bay (-AB), 
s.d., E. Esterhuysen 30533a (BOL111724); Cape Peninsula, Buffels Bay (-AB), 8 Nov. 1963, T. Norlindh 5973 (PRE; S08-11647).

\section{Acknowledgements}

I am grateful to the curators of the Herbarium of the Natural History Museum, London; the Bergius Herbarium, Bergius Botanic Garden, Stockholm; and the Thunberg Herbarium, Museum of Evolution, University of Uppsala, Uppsala, for making high-resolution digital images of type material available. The curators of the following herbaria are thanked for allowing access to their holdings: the Bolus Herbarium, University of Cape Town, Cape Town; Compton Herbarium, South African National Biodiversity Institute, Cape Town; herbaria of the Conservatoire et Jardin botaniques de la Ville de Genève, Geneva; National Herbarium, South African National Biodiversity Institute, Pretoria; Selmar Schonland Herbarium, Albany Museum, Grahamstown; and the Herbarium, Swedish Museum of Natural History, Stockholm. Funding from the Swedish International Development Cooperation Agency-Swedish Research Links (to P.O. Karis) enabled the author to visit the Thunberg Herbarium, Uppsala, the Herbarium, Swedish Museum of Natural History, Stockholm, and the Bergius Herbarium, Stockholm. Three anonymous reviewers are thanked for suggestions to improve the manuscript.

\section{Competing interests}

The author declares that he has no financial or personal relationships that may have inappropriately influenced him in writing this article.

\section{References}

Aiton, W., 1789, Hortus kewensis; or, a catalogue of the plants cultivated in the Royal Botanic Garden at Kew, vol. 3, G. Nicol, London.

Aiton, W.T., 1813, Hortus kewensis; or, a catalogue of the plants cultivated in the Roya Botanic Garden at Kew, by the Late William Aiton, vol. 5, 2nd edn., Longman, Hurst, Rees, Orme \& Brown, London.

Beauverd, G., 1915, 'Contribution à l'étude des Composées (suite X)', Bulletin de la Société botanique Genève, série 27, 21-56.

Bergius, P.J., 1767, Descriptiones plantarum ex Capite bonae spei, cum differentiis specificis, nominibus trivialibus, et synonymis auctorum justis, L. Salvii, Stockholmiae.

Burman, N.L., 1768, 'Florae capensis prodromus', in N.L. Burman (ed.), Flora indica: cui accedit series zoophytorum indicorum, nec non prodromus florae capensis, $\mathrm{pp}$. 1-32 [numbered separately], C. Haek, Lugduni Batavorum; and J. Schreuderum, Amstelaedami.

Candolle, A.P. de, 1838, Prodromus systematis naturalis regni vegetabilis, sive enumeratio contracta ordinum, generum, specierumque plantarum huc usque cognitarum, juxta methodi naturalis normas digesta, vol. 6, Treuttel \& Würtz, Paris.

Desmond, R., 2007, The history of the Royal Botanic Gardens Kew, 2nd edn., Kew Publishing, London.
Diment, J.A. \& Wheeler, A., 1984, 'Catalogue of the natural history manuscripts and letters by Daniel Solander (1733-1782), or attributed to him, in British collections', Archives of Natural History 11, 457-488. https://doi.org/10.3366/ collections', Archives
anh.1984.11.3.457

Glen, H.F. \& Germishuizen, G. (compilers), 2010, Botanical exploration of Southern Africa, 2nd edn., South African National Biodiversity Institute, Pretoria.

Gmelin, J.F., 1792, Caroli a Linné, ... Systema naturae per regna tria naturae, secundum classes, ordines, genera, species, cum characteribus, differentiis, synonymis, locis, 13th edn., tomus 2, pars 2, Georg Emanuel Beer, Lipsiae.

Gmelin, J.F., 1796, Caroli a Linné, ... Systema vegetabilium, secundum classes ordines, genera, species; Cum characteribus, differentiis, tomus 2, Bernuset, Delamolliere, Falque et Soc., Lugduni.

Harvey, W.H., 1865, 'Compositae', in W.H. Harvey \& O.W. Sonder (eds.), Flora capensis, being a systematic description of the plants of the Cape Colony, Caffraria and Port Natal, pp. 44-530, vol. 3, L. Reeve, London.

Le Roux, M., Wilkin, P., Balkwill, K., Boatwright, J.S., Bytebier, B., Filer, D. et al., 2017 'Producing a plant diversity portal for South Africa', Taxon 66, 421-431. https:// doi.org/10.12705/662.9

Lessing, C.F., 1832, Synopsis generum compositarum earumque dispositionis novae tentamen, monographiis multarum capensium interjectis, Duncker \& Humblot, tentamen,
Berlin.

Lewin, K., 1922, 'Systematische Gliederung und geographische Verbreitung der Arctotideae - Arctotidinae', Repertorium Specierum Novarum Regni Vegetabilis, Beihefte 11, 1-75.

Marshall, J.B., 1978, 'The handwriting of Joseph Banks, his scientific staff and amanuenses', Bulletin of the British Museum (Natural History) Botany 6, 1-85.

McKenzie, R., 2012, 'Arctotis L.', in J. Manning \& P. Goldblatt (eds.), Plants of the Greater Cape Floristic Region, vol. 1: The core Cape flora, Strelitzia, vol. 29, pp. 353-356, South African National Biodiversity Institute, Pretoria.

McKenzie, R.J., 2018, 'Nomenclatural changes and typifications of Arctotis species (Asteraceae, Arctotideae) from the Western Cape and Eastern Cape provinces of South Africa', Willdenowia 48, 29-49. https://doi.org/10.3372/wi.48.48103

McKenzie, R.J. \& Barker, N.P., 2010, 'Typification of names in nine species of Arctotis (Asteraceae, Arctotideae) from the Succulent Karoo, South Africa', Novon 20, 298-302. https://doi.org/10.3417/2009031

McKenzie, R.J. \& Barker, N.P., 2013, 'The identity of Damatris pudica Cass. and typification of Arctotis breviscapa Thunb. (Asteraceae, Arctotideae)', Phytotaxa 121, 57-60. https://doi.org/10.11646/phytotaxa.121.1.3

McKenzie, R.J., Hjertson, M. \& Barker, N.P., 2008a, 'Typification of the name Arctotis lanata and those of some southern African Haplocarpha species (Asteraceae, Arctotideae)', Taxon 57, 612-614.

McKenzie, R.J., Hjertson, M. \& Barker, N.P., 2008b, 'Typification of Arctotis plantaginea and names in the Arctotis semipapposa species complex (Asteraceae, Arctotideae)', Taxon 57, 1341-1346.

Murray, J.A., 1798, Caroli a Linné equitis Systema vegetabilium secundum classes ordines genera species cum characteribus et differentiis, 15th edn., Jo. Christ. Dieterich, Gottingae.

Norlindh, T., 1964, 'On the identity of Arctotis stoechadifolia Berg.', Svensk Botanisk Tidskrift 58, 193-203.

Rose, E.D., 2018, 'Specimens, slips and systems: Daniel Solander and the classification of nature at the world's first public museum, 1753-1768', British Journal for the History of Science 51, 205-237. https://doi.org/10.1017/S0007087418000249

Sprengel, C., 1827, Caroli Linnaei,... Systema vegetabilium, 16th edn., vol. 4(1), Librariae Dieterichianae, Gottingae.

Stafleu, F.A. \& Cowan, R.S., 1976, Taxonomic literature: A selective guide to botanical publications and collections with dates, commentaries and types, 2nd edn., vol. 1, Regnum Vegetabile 94, Bohn, Scheltema \& Holkema, Utrecht.

Thiers, B., 2018, Index Herbariorum: A global directory of public herbaria and associated staff, Botanical Garden's Virtual Herbarium, New York, viewed 19 May 2018, from http://sweetgum.nybg.org/ih/.

Thunberg, C.P., 1799, Arctotis, quam dissertatione botanice delineatum, venia exp. Ord. med. Upsal. praeside Carol. Pet. Thunberg... publicae censurae submittit. Carolus Johannes Afzelius, westrogothus, stip. Victorianus, J. F. Edman, Upsaliae.

Turland, N.J., Wiersema, J.H., Barrie, F.R., Greuter, W., Hawksworth, D.L., Herendeen, P.S. et al. (eds.), 2018, International code of nomenclature for algae, fungi, and plants (Shenzhen Code) adopted by the Nineteenth International Botanical Congress Shenzhen, China, July 2017, Regnum Vegetabile 159, Koeltz Botanical Books, Glashütten.

Willdenow, C.L., 1803, Caroli a Linné species plantarum exhibentes plantas rite cognitas ad genera relatas cum differentiis specificis, nominibus trivialibus, synonymis selectis, locis natalibus secundum systema sexuale digestas, 4 th edn. vol. 3(3), G.C. Nauk, Berolini. 